\title{
The Character Education in Topeng Malangan Dance Tradition According Transpersonal Psychology Perspective
}

\author{
Kukuh Setyo Pambudi ${ }^{1}$, Billy Qolbinura ${ }^{2}$, Fattah Hanurawan ${ }^{3}$ \\ ${ }^{1}$ Faculty of National Security, Universitas Pertahanan \\ ${ }^{23}$ Faculty of Psychology, Universitas Negeri Malang \\ Correspondent: kukuhpambudi@ymail.com
}

Submitted : June 27, 2020 Revised : July 16, $2020 \quad$ Published : July 30, 2020

\begin{abstract}
The aim of this research is to uncover the presence of character building in Topeng Malangan dance tradition according to Transpersonal Psychology perspective. This tradition is one of the art cultural heritage that exclusively from Malang and has some rituals as Silem (meditation) and Suguh. There is something unknown beyond human personality which is connected with spirituality so it is correlated with human's character building. Topeng Malangan dance tradition and all of the rituals inside have contribution and correlation with the character building in the dancer. This research is using qualitative research method with ethnography. It founds that sub-personality and some objects in transpersonal psychology has significant result in building character education at Malang mask dance.

Keywords: Character Education, Topeng Malangan dance, Transpersonal Psychology, SubPersonality
\end{abstract}

\section{INTRODUCTION}

Character in society is the most important part from a culture in a country that has an invisible strong ideology (Suyata, 2011). Character is also described by Mardapi (2011) as a people's disposition that can be good or bad based on the environment. On the other side, character is also described as unfinished spiritual yet, it could be changed and developed the quality but also can be abandoned so there will be no increasing quality or even worse (Saptono, 2011). Based on those descriptions can be known that character is the most important thing in a social life, individual character can be planted and developed the quality. Usually character is used for showing how good is someone.

Character education can be inside some application, directly seed in or even not. Art is one of another part which could plant character. Suyata (2001) said that character education needs conceptual based character and comprehensible moral with clearly culturally based.

Art is one shape of human vessel in express their heart. With its stimulus, it could be conveyed to the connoisseurs of art effectively because it is easier to touch the deepest soul from the people (Hadi, 2007). This is one of the function of art as the educational media and submission of information. Information in art often has certain meaning and character building. It could be looked from the variation of the story which has the storyline and the specific character, like Wayang and Sendratari. Besides from the educational and submission of information media, actually there are some kind of arts that used by the creator as a media for ritual approach to god (Supriyanto, 1997). Therefore, its journey with some rituals inside the art could be one of the media as character education. 
Tari Topeng Malangan (Malang Mask dance) Tradition is one of the artistic show from Malang, East Java, Indonesia. This art has the particularity that closely related with people's lives in Malang historically. The Mask is the identity of this art as the main property of the dance. The story tells about Panji saga from the legend of Jenggolo and Kediri Kingdom, both of them are in the East Java. Jenggolo and Kediri Kingdom is two Kingdoms that ultimately merge into one under the leadership of the Kediri Kingdom. The character of the Malangan Mask was token from the Kingdom's Panjis saga.

In each Malang Mask Dance show, there are several phase that must be passed. Based on the interview with respondents, some house before the show are Silem and Suguh. Silem is phase before the show by meditation which aims to ask a guide from the ancestor, and Suguh is the phase that done by giving regale to the spirit of the ancestor. Those activities were done in the holy place around the Sanggar (studio) like Pundhen and Belik. It is some kind of bath place in the side of Metro river.

Like the other art, this Malang Mask Dance also has some messages and character education in each of the show. In addition of the show, the ritual that has been done builds the character of the mask to the dancer. The connection between rituals and the character could cause transmission transcendentally. This transmission is between human and something correspond with spirituality. McWater (in Mujidin, 2005) propose about method to develop dimensions in transpersonal psychology object. Those dimensions are intuition, psychological-spiritual, mystical, and integrity. The ritual in Malang Mask dance is one of the aspect of developing method inside the transpersonal psychology dimensions. The aim of this research is to reveal the presence of character education in Malang Mask dance tradition from the transpersonal psychology perspective.

\section{METHOD}

This research was using qualitative method and the purpose of this research was to explore the character education in Topeng Malangan dance according to Transpersonal Psychology perspective. The objective of qualitative research is to describe and possibly explain events and experiences, but never to predict. Qualitative researchers study people in their own territory, within naturally occurring settings (Willig, 2008). The data was collected with Ethnography design and used in-deep interview since March to April 2015. Through in-deep interview techniques, the researchers can obtain all information about the true story behind the required rituals before practice the dance, and we could find how those things affected their spirituality and influenced their personality from the character building. The in-deep interview was recorded using smartphone and the responses were transcribed and analyzed after the end of the interview. The collected data were analyzed using thematic analysis technique. Here, the researchers did some identification, analysis, and reporting themes from the data (Braun \& Clarke, 2006; Hanurawan, 2012), the procedures were making categories from the collected themes, giving codes to each category, and validating the conclusion. The subject is the $5^{\text {th }}$ generation and also the owner of Asmoro Bangun Malang traditional dance studio, he is the great-grandson of the Malang Mask dance's creator, his mother as the wife of the $4^{\text {th }}$ generation, and a Traditional Dance and Art student of Universitas Negeri Malang who had some experience with the Topeng Malangan dance. The interview was held in the Asmoro Bangun Pakisaji and Universitas Negeri Malang. As the result of the research were assembled, we validated member check. In this context, we checked 
The Character Education in Topeng Malangan Dance Tradition According Transpersonal Psychology Perspective Pambudi, Qolbinura, \& Hanurawan

the data by asking to another subject who really understand too with the history of Topeng Malangan dance. For the member check we asked again our main subject with different questions, but the questions still digging the same thing with the first interview. The interview used Indonesian language and translated into English by the researcher.

\section{RESULT AND DISCUSSION}

Based on the data from In-depth interview and observation, the data could be generalized into six main aspects. Those are signification of mask, the process of the ritual, the dancer participation in the ritual, knowledge about the mask's character, the creation of the character of the mask, and the character appreciation in real life. The result is validated by member check.

The subject interpret the mask as the manifestation of the ancestor which "represented" to be a mask. Subject assume the mask is the gate for connecting and interacting with the ancestor. Subject also gave an example about the show, when he used the mask, he assumed himself as a car and the ancestor is the driver. This is looked like a trance condition.

The treatment (ritual) of the mask by the subject is also carried out in a particular way. This special treatment should be done due to the signification. The subject told that there are some treatments (rituals) that should do, like putting the mask in Punden (holy place) on the night before the show, another treatment is by do not lend the mask to another dancer. Here illustrated that the subject idolize the mask in their daily life. Based on what the subject described is, it could be concluded that the mask is the manifestation of the ancestor and should be treated carefully.

Before the show and the practice, the subject explained that there are some rituals, those are Silem and Suguh. Silem is a ritual that should be done a long time before the show and the last night before the show too. The aim of this ritual is to get an interaction with the ancestor. The interaction happen in order to give the subject some kind of guidance and easiness during the show. Silem is also done when the subject create the mask. In the process, Silem done by meditation in a holy place (Punden). The subject explained that during the meditation, he could communicate with the real figure of the ancestor.

The second ritual is Suguh. This ritual is done by giving some serving to the ancestor. This ritual should be done before the show. Subject explained that the serving are a myrrh and some flowers put in a vessel near the stage and on the Punden. From the subject's explanation, it could be concluded that in the preparation process until the show there are two main rituals that should be done. Those rituals assumed as the way to get interaction and getting closer with the ancestor. Besides that, the other purpose of the ritual is to give safety during the show.

For the role of the dancer, subject explained that each dancer has responsibility in one character of the mask, it has been some kind of specialize from that dancer. The dancer more involved in the preparation until the show. But in some rituals, the dancer get involved too, especially Suguh and Silem. During the rituals, the dancer should bring their own mask, and give the mask special treatment in the rituals. The aim is to make the mask become one with the ancestor of the character of the mask. The mask could not be used by anyone else except the owner.

However, not all the dancer do these things. There are some dancer that do not follow the rituals, this kind of dancer usually only learn how to dance without knowing more about the dance and the mask. The subject said that this kind of dancer cannot be juxtaposed with the dancer who did the whole rituals. It is obvious from the mastery of the dance, appreciation the character of 
the mask. The dancer that do not follow the rituals only dance by the music with no soul. It is happened because when the dancer do all of the rituals, the character will be brought into daily life.

The fused of the mask's character with the dancer's personality in daily life could be easier to see in the antagonist character such as "Bapang" and "Klono". Based on the data, the dancer is not only dancing, but also following the process of the rituals. The dancer which follows the rituals will be had the character of the mask becomes his or her character in daily life.

Most of the subjects know the entire character in Malang Mask dance. The knowledge of the character could be seen when the subject explain about the name of the character and told about each treats. Besides that the subjects could explain the detail about the history of the characters, the subjects also explain about actually each dancer has their own specialize character, but before they decide about their character, they should learn all the characters and the movements.

The process of creating the mask is also has some rituals. The character is believed as the manifest of the ancestor which cannot be created carelessly, a mistake in making the mask can be something bad for the dancer or even the whole show.

Silem is the ritual of creating the mask, meditation in Silem has a purpose to get some image about the character of the ancestor then they can craft it in the wood and become a mask. The subject explained that when he did the Silem, he was visited by the ancestor, and told him about the character. It makes him more convinced about the character. Based on the data it could be concluded that in the process of creating the mask, they have a Silem ritual, and the aim of it is to get the image of the character.

The subject described that basically each dancer has their own character as the specialization. The specialization makes the dancer more understand the character deeply. Subject also explained that to know the character of their self needs a long time, because before having the character, they need to learn all of the character of Malang Mask Dance.

The specialization does not choose by the mentor only, but also with another deeply approach or in this case with the rituals. They need to do the rituals for knowing the character from the ancestor so they will have the character in their daily life. This phenomenon found in 3 dancers, there are some kind of bond between their self and the mask. From all of the data, it could be concluded that the mask character could be became the dancer character with a long ritual process.

Appropriate with McWaters theory about Transpersonal Structure (in Mujidin, 2005). The result of the research showed that Character education in the Malang Mask Dance is one of the phenomena that could be seen from Transpersonal Psychology perspective. All of the thing could be included to transpersonal psychology because of some aspects, such as rituals procession and believes which is used to transcend their self.

Self-transfering process is one of the object which has very strong correlation with transpersonal psychology, in this dance ritual process we can find silem ritual. this ritual is seems like meditation. This ritual is included as one of psychic-dimension development from human transpersonal structure because there is an effort to self-transend from sencoric condition. This ritual also can be seen as intuitive dimension, cause when the silem process is running, the idea of mask character making can be achieved. Besides, in Suguh ritual we also can see mystical dimension, cause in this ritual the sesajen (gift) is given to ancestor's spirit which believed attending 
when tha dance begin. The last dimension can be seen from the continuity of both 3 dimension before in the mask dance procession and character education which exist inside.

Besides in the transpersonal dimensions, character education in the Malang Mask dance could be seen also by transpersonal psychology perspective. That is because of character education in the Mask dance is one of transpersonal psychology study object. Like what has Noesjirwan (2000) said that transpersonal psychology's object is covering some condition, such as consciousness, the highest potential, through the ego or trans-ego, transcendence, and spirituality.

The link between transpersonal with Malang Mask Dance and character education inside it could be seen from the process that have been done. The most-transpersonal object is transego, transcendence, and spirituality. Those are because of the whole processes in the Malang Mask dance produce the character education on transpersonal way by transcending some object, like in the Silem ritual, where the subject feels their self in the border of consciousness and unconsciousness. In the other side, the ritual process is some kind of believe that connected them with their ancestor spirits, so it could be said that this object included to spirituality object. The last one is trans-ego object. The character educations here facilitated subjects to make them free from their personality and becoming the other personality like in the mask that they roled.

Besides it could be explained by transpersonal structure and the objects in transpersonal psychology, character education in the Malang Mask dance is also could be explained by subpersonality concept by Assigioli (1973). In his theory, Assigioli explained an image about consciousness and the structure that built it. One thing that has a significant effect in determining human personality is sub-personality part (look at picture 1). This part is divided from groups of

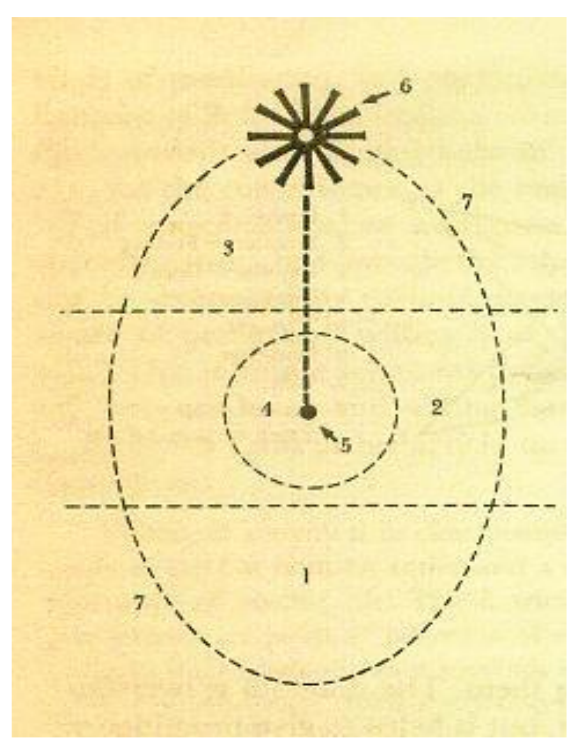
"role" which is internalized by them to become their personality, that is why John Rowan (1990) explained that sub-personality is the people inside us.

(Source : Assigiolli, 1973) 
The Character Education in Topeng Malangan Dance Tradition According Transpersonal Psychology Perspective Pambudi, Qolbinura, \& Hanurawan

\section{CONCLUSION}

Topeng Malangan Tradition is one of tradition in Malang, East Java. This tradition is a form of mixing the two culture between people's puppet and standard puppet. The mask is the main accessory from the dance and one of the sacred shape from the show at once. The mask becomes reference by the dancer in each movement of the dance. Otherwise, the characters of the mask which believed to be a form of the ancestor. Due to that reason, before in each show, there are some special phase to do such a ritual. The ritual that given to the mask believed to make the soul of the ancestor inside the mask could get into the dancer, so there will be a continuity.

The character of the mask often built into the dancer as long as they do the rituals. Besides as the shape of deepening the character of the mask, it is also believed as the result of the ritual that must be done before the show. The rituals contain of silem and suguh. Silem is phase before the show by meditation which aims to ask a guide from the ancestor, and Suguh is the phase that done by giving regale to the spirit of the ancestor. Which those rituals are connected with Selftransferring process.

Transpersonal psychology divided into two, personal and transpersonal. Inside the transpersonal one, it is divided again become four dimensions, those are intuition, psychologicalspiritual, mystical, and integration. There is also a developing of transpersonal dimensions in the Malang Mask dance from the rituals. The character formation is one of the important thing in transpersonal. Besides in the transpersonal dimensions, character education in the Malang Mask dance could be seen also by transpersonal psychology perspective. That is because of character education in the Mask dance is one of transpersonal psychology study object. This could be explained by sub-personality concept.

\section{REFERENCE}

Assagioli, Roberto. (1973). The Act of Will. United States of America : The Viking Press Hadi, Sumandiyo. (2007). Sosiologi Tari. Yogyakarta: Pustaka.

Hanurawan, Fattah. (2012). Metode Penelitian Kualitatif Dalam Ilmu Psikologi. Surabaya: KPKM Unair

Hidajat, R. (2009). Struktur, Simbol, Dan Makna Wayang Topeng Malang. Bahasa dan Seni, 33(2). Mardapi, Djemari. (2011). "Penilaian Pendidikan Karakter". Dalam Darmiyati Zuchdi (Ed.)

Pendidikan Karakter dalam Prespektif Teori dan Praktik. Yogyakarta: UNY Press.

Minarto, Soerjo. (2010). Bahasa dan Seni, tahun 38 No. 1.93 - 106

Mujidin. (2005). Humanitas: Indonesian Psychological Journal Vol. 2 No. 1.54 - 64

Saptono. (2011).Dimensi-dimensi pendidikan karakter: Wawasan, strategi, dan langkah praktis. Jakarta: Esensi

Supriyanto, Heri dan Pramono, Soleh Adi. (1997). Drama Tari, Wayang Topeng Malang. Malang :Padepokan seni Mangun Dharma

Suyata. (2011) . "Pendidikan Karakter: Dimensi Filosofis", dalam Darmiyati Zuchdi (ed.). 2011 .

Pendidikan Karakter dalam Perspektif Teori dan Praktik. Yogyakarta: UNY Press.

Willig, Carla. (2008). Introducing Qualitative Research in Psychology. Berkshire: Open University Press. 